\title{
Granulocytic Sarcoma of the Sciatic Nerve Manifested as Relapse of Acute Myeloid Leukemia: A Case Report
} 좌골신경의 과립세포육종으로 재발한 급성 골수성 백혈병: 증례 보고

\author{
Seung Eun Lee, $\mathrm{MD}^{1}$ (D), Yosep Chong, $\mathrm{MD}^{2}$, Seok Whan Song, $\mathrm{MD}^{3}$, \\ Jeongmi Park, $\mathrm{MD}^{1 *}$ (D)
}

Departments of ${ }^{1}$ Radiology, ${ }^{2}$ Hospital Pathology, ${ }^{3}$ Orthopedic Surgery, Yeouido St. Mary's Hospital, The Catholic University of Korea College of Medicine, Seoul, Korea

Granulocytic sarcoma is a form of extramedullary involvement of primitive myeloid cells. A 69-year-old male patient, with history of acute myeloid leukemia (AML) in remission state for 4 years, presented numbness, radiating pain and progressive motor weakness in left leg. MRI showed perineural thickening of the left sciatic nerve with increased signal intensity on fat-saturated T2-weighted image. The patient underwent surgical excision and the pathology was confirmed as granulocytic sarcoma. Its involvement of the peripheral nerve is extremely rare and also unusual to be the only evidence of AML relapse. In this case, we figured out the MRI feature of granulocytic sarcoma involving sciatic nerve, emerged as a sole manifestation of AML relapse.

Index terms Sarcoma, Myeloid; Leukemia, Myeloid, Acute; Neoplasm Recurrence, Local;

Magnetic Resonance Imaging; Peripheral Nerves
Received April 19, 2018

Revised June 28, 2018

Accepted August 3, 2018

${ }^{\star}$ Corresponding author Jeongmi Park, MD Department of Radiology, Yeouido St. Mary's Hospital, The Catholic University of Korea College of Medicine, 1063-ro, Yeongdeungpo-gu, Seoul 07345, Korea.

Tel 82-2-3779-2037

Fax 82-2-783-5288

E-mail jmpark@catholic.ac.kr

This is an Open Access article distributed under the terms of the Creative Commons Attribution Non-Commercial License (https://creativecommons.org/ licenses/by-nc/4.0) which permits unrestricted non-commercial use, distribution, and reproduction in any medium, provided the original work is properly cited.

\section{ORCID iDs}

Jeongmi Park (D) https:// orcid.org/0000-0001-7198-4201 Seung Eun Lee (D) https:// orcid.org/0000-0002-2951-7869

\section{INTRODUCTION}

Granulocytic sarcoma, also called myeloid sarcoma or chloroma, is a localized tumorous lesion of primitive myeloid cells at extramedullary site (1). Granulocytic sarcoma can occur in any tissue, but the most common locations are soft tissues, bone, peritoneum, lymph nodes, and gastrointestinal system. Other sites that are presented in literatures are the genitourinary system and central nervous system (CNS) including spinal nerve (2). The involvement of the peripheral nerve is extremely rare and only a few cases were reported as relapsed acute myeloid leukemia (AML) with other con- 
comitant systemic involvement. Herein, we report a case of granulocytic sarcoma in the sciatic nerve presenting with leg pain and numbness as the only manifestation of relapse of AML.

\section{CASE REPORT}

A 69-year-old man presented with numbness and radiating pain on his left leg, mainly in left lower leg and left sole. Also the posterior muscles of left lower leg were gradually atrophied. His symptom had been aggravated for 6 months. He had a history of 4 years of chemotherapy for AML, which had been in complete remission state. On physical examination, he showed a progressive weakness in plantar flexion and inversion of his left foot. The electromyography showed compatible findings with left sciatic neuropathy at mid-thigh, including tibial division. The initial laboratory test revealed a normal range of white blood cell count $\left(8.09 \times 10^{3} / \mu \mathrm{L}\right)$ and platelet count $\left(219 \times 10^{3} / \mu \mathrm{L}\right)$, and mildly decreased level of hemoglobin $(12.8 \mathrm{~g} / \mathrm{dL})$. There was no abnormal blast form of erythrocyte, leukocyte, and platelets in peripheral blood. Since he slipped down a few months ago, these symptoms and signs were regarded as traumatic neuritis at first. However, even after the medication and left sciatic nerve block with steroid injection, his symptom was aggravated.

The patient was admitted for further diagnostic workup and repetitive nerve block, including the MRI of the left leg. MRI scan of left thigh demonstrated intermediate signal intensity of the sciatic nerve on both axial T1 and fat-saturated T2-weighted images (Fig. 1A, B). The sciatic nerve was surrounded by thickened peripheral nerve sheath which shows markedly high signal intensity on fat-saturated T2-weighted images and intermediate signal intensity on T1-weighted image (Fig. 1A, B). Also, prominent enhancement of peripheral nerve sheath was noted on gadolinium-enhanced axial T1-weighted MRI, but the sciatic nerve itself showed only mild and mottled enhancement (Fig. 1C). On gadolinium-enhanced sagittal T1-weighted MRI, an about $19 \mathrm{~cm}$ length of fusiform enlargement of the sciatic nerve was observed along left distal femur level, with irregular peripheral nerve sheath thickening and enhancement was well demonstrated (Fig. 1D). The patient underwent decompression with epineurectomy and nerve sheath partial excision. During the surgery, the pale brown colored, rubbery to hard sciatic nerve with diffuse enlargement was observed. After epineurectomy of thickened epineurium, the sciatic nerve was exposed and showed mild swollen state. The sciatic nerve resection was not performed considering nerve injury.

Microscopically, there was diffuse infiltration of atypical tumor cells around the nerve fibers and surrounding soft tissue (Fig. 1E). The tumor cells were monotonously angulated or polygonal shaped with hyperchromatic round nuclei and prominent small nucleoli, and eosinophilic cytoplasm. The immunohistochemical staining showed negative for CD3 and CD20 (Ventana, CA, USA, prediluted), but diffuse positive for myeloperoxidase (Ventana, prediluted) (Fig. 1F). The Leder stain for chloroacetate esterase was focally positive. Considering these staining patterns and patient's clinical history, the pathologic result was assumed as leukemic cells derived from the myeloid lineage and lymphoma could be excluded. Finally, the surgical specimens of sciatic and tibial nerve sheath, and perineural fat 
Fig. 1. A 69-year-old-man with granulocytic sarcoma in sciatic nerve.

A, B. Axial fat-saturated T2-weighted image (A) and axial T1-weighted image (B) of MRI of left thigh show diffuse swelling of left sciatic nerve with intermediate $\mathrm{T} 2$ and $\mathrm{T} 1$ signal intensity (open arrows) and irregular peripheral nerve sheath thickening with heterogenous hyperintense T2 signal intensity and isointense T1 signal intensity (thin arrows) at distal thigh level.

C. Contrast-enhanced T1-weighted image shows thick and circumferential enhancement of peripheral nerve sheath (arrow) with internal mild, mottled enhancement of nerve fascicles.

D. Sagittal contrast-enhanced T1-weighted image shows an about $19 \mathrm{~cm}$ length of diffuse fusiform thickening and intense enhancement of left sciatic nerve sheath at mid to distal thigh level (arrows). The line indicates the transverse section level of Fig. 1A-C.

E. Histopathology of epineurium and surrounding soft tissue in surgical specimen reveals diffuse infiltration of atypical tumor cells around the nerve fibers and surrounding soft tissue (hematoxylin and eosin stain, $\times 12.5)$. Atypical tumor cells are widely infiltrating epineurium (arrows) and surrounding soft tissue (arrowheads). Specimen contains two small nerve bundles $(\mathrm{N})$ that passes through epineurium. Main nerve fascicle is not included in this specimen.

F. The immunohistochemical staining of tumor cells shows diffuse positive for myeloperoxidase. This result demonstrates that the tumor cells are leukemic cells derived from the myeloid lineage and is important in the diagnosis of granulocytic sarcoma (myeloperoxidase stain, $\times 400$ ).
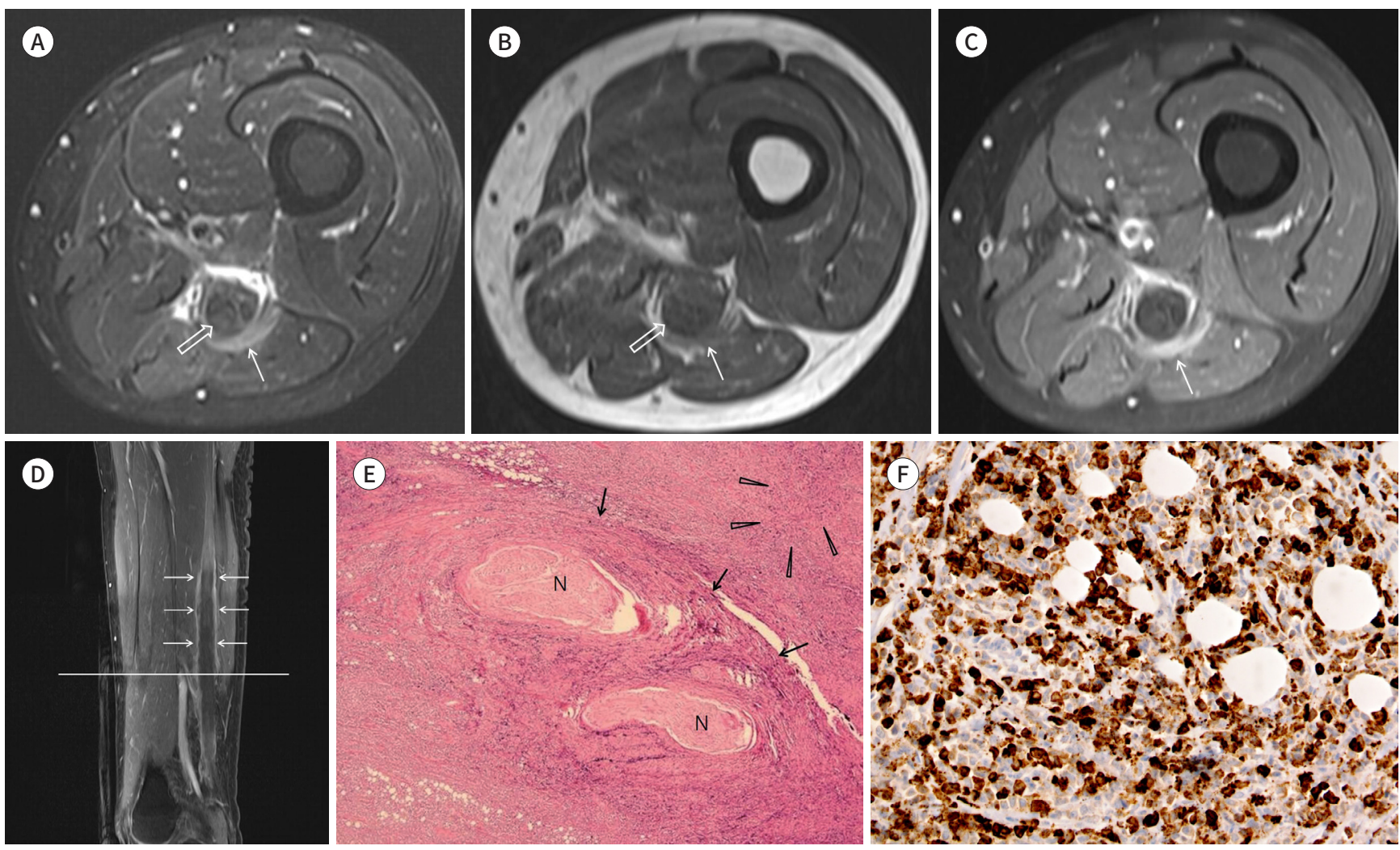

tissue were confirmed as granulocytic sarcoma.

After pathologic confirmation of granulocytic sarcoma, the patient underwent bone marrow biopsy but there was no evidence of systemic relapse of AML. The patient started chemotherapy including cytarabine and mitrone. However, he was lost to follow-up after firstcycle of the treatment.

\section{DISCUSSION}

Granulocytic sarcoma is a rare disease, presented as an isolated solid tumor composed of immature white blood cells called myeloblasts. It is an extramedullary manifestation of AML and can be a manifestation of relapse after successful treatment of AML. According to Novick et al. (3), the prevalence of granulocytic sarcoma of any organ is about 3.1-9.1\% of 
AML patients. Also, the frequency of extramedullary relapse after successful treatment is about $5-12 \%$ of all patients with acute leukemia (4). Vulnerable sites prone to recurrent disease include the testes, CNS, and the eye, followed by breast, paranasal sinuses and gastrointestinal tract (5). Since granulocytic sarcoma rarely presents as the only manifestation of initial expression or relapse of AML, it is very difficult to suspect granulocytic sarcoma as the first diagnosis.

In case of the peripheral nervous system (PNS), extramedullary relapse seems to be much less common than the CNS (6). Granulocytic sarcoma in the PNS usually presents as mono- and polyneuropathies. It has been rarely reported in the literature and, due to a small number of patients, there are no definite imaging findings for this group of patients in consensus (6). Two case reports about sciatic nerve involvement and one case report about median nerve involvement were previously presented (7-9). They were occurred in relapsed AML, but there was other accompanied systemic involvement of AML. In these reports, image findings were demonstrated as either soft tissue mass-forming type, which is also generally shown in other organs, or perineural involvement type. Among these case reports, according to Stillman et al. (7), the lesion is shown as bulgingout mass-forming type, compressing sciatic nerve. In the general cases of mass-forming type involving typical vulnerable sites, it is appeared as discrete solid mass invading and occupying the space of the organ, with isointense to slightly hyperintense signal intensity on T1 and T2-weighted images of MRI and variable enhancement (10). Granulocytic sarcoma is a tumor caused by the infiltration of leukemic cells, which is considered to have high cellularity and show intermediate signal intensity on T2-weighted image. When the granulocytic sarcoma is demonstrated as a mass-forming appearance in the perineural soft tissue of peripheral nerve, abscess, hematoma, lymphoma, and carcinoma can be considered for differential diagnosis because they all can show ambiguous overlapping imaging findings $(7,10)$. On the other hand, perineural involvement type showed longitudinal and circumscribing lesion surrounding the peripheral nerve with the hyperintense signal on the T2-weighted image of MRI and peripheral enhancement (9). This image feature is rather unique finding found in case of nervous system involvement including PNS, compared to generalized mass-forming type. Our MR images demonstrated the similar finding with the case report of Warme et al. (9), which showed marked peripheral nerve sheath thickening with increased signal intensity on the T2-weighted image and enhancement on the gadolinium-enhanced T1-weighted image, suggesting perineural involvement type. Neuritis would be the top differential diagnosis with this image feature. According to pathologic inspection, both perineural involving type of granulocytic sarcoma and inflammatory neuritis can show mature or immature lymphocyte infiltration along the nerve and nerve sheath. Therefore, they might share similar imaging findings such as swelling of nerve and neural sheath on MRI image, and this may lead the radiologist to be confused between these two differential diagnoses.

Although there are only a few sporadic case reports about PNS involvement of granulocytic sarcoma, the reports about CNS, or spinal cord involvement, are better organized. According to Seok et al. (2), when we look at the granulocytic sarcoma of spinal nerve, the lesion usually appears at the epidural space of the central spinal canal, epidural re- 
gion along the nerve root course, thickening of the nerve itself, or a prevertebral lesion. In cases of nerve itself involvement, enlarged nerve without epidural mass is presented on MRI. As compared with our case, which is involving PNS, it is similar that it appears as a nerve enlargement. Thus, through this study about spinal nerve involvement of granulocytic sarcoma, we can confirm the various nerve involvement of granulocytic sarcoma, and one of them shows a finding similar to our case.

In summary, we report a rare case of granulocytic sarcoma involving sciatic nerve, which was the only evidence of relapse in the patient with remission state of AML. Radiologists should be aware of the possibility of granulocytic sarcoma as a differential diagnosis when the patient has the history of AML and the image finding shows atypical mass or severe form of neuritis.

\section{Conflicts of Interest}

The authors have no potential conflicts of interest to disclose.

\section{REFERENCES}

1. Yilmaz AF, Saydam G, Sahin F, Baran Y. Granulocytic sarcoma: a systematic review. Am J Blood Res 2013;3:265-270

2. Seok JH, Park J, Kim SK, Choi JE, Kim CC. Granulocytic sarcoma of the spine: MRI and clinical review. AJR Am J Roentgenol 2010;194:485-489

3. Novick SL, Nicol TL, Fishman EK. Granulocytic sarcoma (chloroma) of the sacrum: initial manifestation of leukemia. Skeletal Radiol 1998;27:112-114

4. Lee KH, Lee JH, Choi SJ, Lee JH, Kim S, Seol M, et al. Bone marrow vs extramedullary relapse of acute leukemia after allogeneic hematopoietic cell transplantation: risk factors and clinical course. Bone Marrow Transplant 2003;32:835-842

5. Clark WB, Strickland SA, Barrett AJ, Savani BN. Extramedullary relapses after allogeneic stem cell transplantation for acute myeloid leukemia and myelodysplastic syndrome. Haematologica 2010;95:860-863

6. Arrigan M, Smyth L, Harmon M, Flynn C, Sheehy N. Imaging findings in recurrent extramedullary leukaemias. Cancer Imaging 2013;13:26-35

7. Stillman MJ, Christensen W, Payne R, Foley KM. Leukemic relapse presenting as sciatic nerve involvement by chloroma (granulocytic sarcoma). Cancer 1988;62:2047-2050

8. Liu HC, Hung GY, Yen HJ, Hsieh MY, Chiou TJ. Acute sciatica: an unusual presentation of extramedullary relapse of acute lymphoblastic leukemia. Int J Hematol 2007;86:163-165

9. Warme B, Sullivan J, Tigrani DY, Fred DM. Chloroma of the forearm: a case report of leukemia recurrence presenting with compression neuropathy and tenosynovitis. lowa Orthop J 2009;29:114-116

10. Ooi GC, Chim CS, Khong PL, Au WY, Lie AK, Tsang KW, et al. Radiologic manifestations of granulocytic sarcoma in adult leukemia. AJR Am J Roentgenol 2001;176:1427-1431 


\section{좌골신경의 과립세포육종으로 재발한}

급성 골수성 백혈병: 증례 보고

이승은 1 정요셉 ${ }^{2} \cdot$ 송석환 ${ }^{3} \cdot$ 박정미 ${ }^{*}$

과립세포육종은 원시 골수 세포의 골수 외 침범으로 인해 생기는 질환이다. 4년간 급성 골수 성 백혈병의 완치 상태로 지냈던 69세 남자 환자가 왼쪽 다리의 마비, 방사성 통증, 그리고 지 속적으로 악화되는 근력 저하를 주소로 내원하였다. 자기공명영상 검사에서 왼쪽 좌골신경 의 신경초가 두꺼워지고 지방억제 $\mathrm{T} 2$ 강조영상에서 신호 증가 양상을 보였다. 환자는 수술적 절제를 받았고 병리학적 검사에서 과립세포육종으로 확진되었다. 과립세포육종이 말초신경 을 침범하는 것은 매우 드물고, 또한 급성 골수성 백혈병의 재발 형태로 유일하게 발현하는 것 역시 매우 드물다. 우리는 급성 골수성 백혈병이 단독으로 좌골신경에 재발된 증례를 자 기공명영상 소견과 함께 보고 한다.

가톨릭대학교 의과대학 여의도성모병원 ${ }^{1}$ 영상의학과, ${ }^{2 ㅂ ㅕ ㅇ ㄹ ㅣ ㅎ ㅏ ㄱ ㄱ ㅘ, ~}{ }^{3}$ 정형외과 